\title{
PERFORMANCE OF FRUIT VEGETABLES IN SUMMER UNDER MAHAGONY BASED AGROFORESTRY SYSTEMS
}

\author{
Tania Sultana* ${ }^{* 1}$, Sazedatur Rahman ${ }^{1}$, Nazmun Naher $^{1}$, Raja Md. Masum ${ }^{1}$, Abdul Halim ${ }^{1}$ Arif Ahmed $^{1}$, Rabiul Islam ${ }^{2}$ \\ ${ }_{1}^{1}$ Department of Agroforestry and Environmental Science, Sher-e-Bangla Agricultural University, Dhaka -1207, Bangladesh \\ ${ }^{2}$ Department of Agricultural Chemistry, Sher-e-Bangla Agricultural University, Dhaka -1207, Bangladesh \\ *To whom correspondence should be addressed. Email: kbdtania06@yahoo.com
}

This is an open access article distributed under the Creative Commons Attribution License, which permits unrestricted use, distribution, and reproduction in any medium, provided the original work is properly cited.

\section{ARTICLE DETAILS}

Edited by:

Md. Mahmudul Hasan, Jessore University of Science and Technology, Jessore-7408, Bangladesh. Email: drhasan_nft@just.edu.bd

\section{Reviewed by:}

\section{AkM Alam}

Bangladesh Agricultural Research

Institute Gazipur, Bangladesh

Email: akmliton@yahoo.com

2. Md. Amirul Islam International Maize and Wheat Improvement Center (CIMMYT)-Bangladesh

Email: musa_amirul@yahoo.com

Received 10 May 2018

Revised 01 June 2018

Accepted 12 June 2018

Available online 1 July 2018

\section{ABSTRACT}

An experiment was conducted at central experimental field of Sher-e-Bangla Agricultural University, Sher-e-Bangla Nagar, Dhaka, Bangladesh during March to June, 2016 to evaluate the performance of summer vegetables under reduced light condition in Mahagony based agroforestry systems. The selected vegetables were also grown in control (i.e., open field condition). The vegetables were Chili, Egg plant and Okra and treatments were (a) Tsun = under full sunlight and (b) Tshade = under shade condition (reduced light intensity). The experiment was laid out following single factor RCBD design. The aim of the study was to select best fruity vegetables which are suitable for inclusion under shade condition in mahagony based agroforestry systems. During the study period maximum light intensity reduction was recorded in case of chilli $(42.23 \%)$ and minimum light intensity was reduced in case of Eggplant (25.42\%) in shade. The shade had substantial effects on fruity vegetables concerning various growth parameters. From the results of the study, it was exhibited that there were significant variation in respect of plant height under shade condition, with the significantly highest yield per hectare was recorded for 0kra ( 21.66 ton/ha) under reduced light condition. All the other vegetables showed highest yield per plot and yield per hectare when grown under full sunlight.

\section{KEYWORDS}

Agroforestry, Reduced Light, Fruit vegetables, yield.

\section{INTRODUCTION}

Bangladesh is one of the most densely populated country of the earth struggling hard to feed her 15.47 crore people [1]. If the present population growth rate $(1.37 \%)$ continues, population will increase to 180 million by the year 2025 , and the country will face huge problems to nurse her population. The economical strength and stability of the country mostly depends on agriculture sector that contributes $16.33 \%$ in total GDP [2]. About $80 \%$ of the total population live in rural areas and are directly dependent on agriculture for their livelihood. The country has only a land area of 14.39 million hectares, but due to the ever-growing population, per capita land area is decreasing at the rate of $0.05 \mathrm{ha} / \mathrm{cap} /$ year since 1989 and therefore steadily declining the land: man ratio [3].

Like agriculture, the important resources i.e.; forest is declining also with increasing population. Forestry plays an important role in maintaining environmental balance and socio-economic aspects of the people. A country needs $25 \%$ of forest land of its total area for ecological stability and sustainability. Unfortunately, Bangladesh is endowed with only $17 \%$ of unevenly distributed forests [4]. However, actual tree cover is less than $10 \%$ of unevenly distributed forests Bangladesh has only $17 \%$ (2.52 mha) of land designated as forests although FAO estimates $11 \%$ (1.442 mha) as effective forest cover [5-7]. The central region where the population density is the highest, has the least forest resources. The demand and supply of fuel wood are 310 and 125 million cft., respectively, and those for timber are 115 and 44 million cft., respectively [8]. respectively. This large demand of wood has created a tremendous pressure on the reserved forests. For instance, reserve forests depleted by 61\% between the year 1963 to 1983 [9]. Substantial depletion of forest resources has occurred in the last few decades, and now it is reduced to less than 0.02 ha per person, which is one of the lowest ratio in the world [10]. Under these alarming situations, agricultural production as well as forest resources must be increased by using modern or new techniques. Recently, some techniques have already been advocated to overcome the future challenges, agroforestry is one of them. Understory crops including vegetables can be integrated with forestry, orchard, or other agroforestry systems. Farmers use understory crops to get earlier returns, diversity products, and/or to make more efficient use of land and labor [11]. Growing of annual crops in association with trees are becoming popular day by day for their higher productivity, multipurpose use and environmental consciousness among peoples. But farmers face problems of growing crops after $4-5$ years of tree plantations and even sometimes fail to grow understory crops under and around trees.

In agroforestry systems, among different production limitations, availability of light may be the most important limitation to the performance of the understory crops/vegetables particularly where an upper storey perennial forms a continuous overstorey canopy [12]. Light is the basic element that provides energy for photosynthesis which is the basis of crop production. First, there is the fraction of photosynthetically active radiation (PAR) that is intercepted by every species. Second, there is the efficiency with which intercepted radiation is changed to biomass. Willey stressed on more efficient use of light than the amount of light interception in different stages of crop production [13]. However, under a 
given site condition, availability of light to the understory crops/vegetables is dependent on the trees characteristics such as crown shape and density, size of the tree and tree management practices.

For identifying the compatibility of tree-vegetable combination, particularly under storey species i.e. different vegetables should be screened out in terms of their adaptability and production under different shade levels created by the upper storey tree species. For this purpose, the best way is to produce different vegetables beneath different tree species. But the light transmission ability of a tree species not only depends on tree species but also several other factors such as age of the tree, growth pattern of the tree etc. So, it will not be wise to conduct an experiment i.e. trial and error under farmers conditions before knowing the responses of the crops under different reduced light levels. Therefore, it would be better to conduct experiments under artificial shade condition for screening of different vegetables in terms of their growth and yield performance.

In Bangladesh, most of the vegetables grow in winter. Among the very few summer vegetables Indian Spinach, Data, Kangkong, Okra, chilli, eggplant are very common. But unfortunately, very few studies have been found to screen out different summer vegetables in terms of adaptability and yield under shade created by the upperstorey trees. In this situation, the present study of interaction performance of three fruit vegetables under reduced light levels i.e., full sunlight and reduced light will be a pioneer to introduce higher yielding and partial shade tolerant summer vegetables. The objectives of the study were (a) evaluation of the yield and yield contributing characters of three summer vegetables under reduced light intensity (b) to identify the most suitable and adaptive summer vegetable species for agroforestry systems.

\section{METHODS AND MATERIALS}

The experiment was conducted at the central experimental field of Shere-Bangla Agricultural University, Sher-e-Bangla Nagar, Dhaka, Bangladesh. The experiment was conducted for screening of some higher yielding and partial shade tolerant summer vegetables in open field condition i.e., full sunlight and reduced light intensity under Mahagony (Swietenia macrophylla) based agroforestry system during the period from March to June, 2016. Swietenia macrophylla (Family- Meliaceae) is promising important timber species for agroforestry due to less competition of root due to deeper rooting nature, multipurpose tree, moderate fast growth, adoptability, remarkable wood qualities, better form and higher sown out turn, amenability to stand management practices etc. are some of the features that endear among the tree farmers. Samples of soil were collected from the experimental plots to a depth of 0$15 \mathrm{~cm}$ from the surface before initiation of the experiment and analyzed soil physical properties in the laboratory. The soil was having a texture of sandy loam having pH and Cation Exchange capacity 5.6 and 2.64 meq 100 $\mathrm{g} \mathrm{soil}^{-1}$, respectively. In this study shading was created by Mahagony forest (three line of Mahagony tree where tree to tree spacing $2.5 \mathrm{~m}$ and line to line spacing $3 \mathrm{~m}$ ) in two side (east and west) of crop field. Two treatments were used in this experiment. $\mathrm{T}_{\mathrm{sun}}=$ Planting summer vegetables under full sunlight (open field condition) and $\mathrm{T}_{\text {shade }}=$ Planting summer vegetables under reduced light intensity (under Mahagony based agroforestry system). In treatment $\mathrm{T}_{\text {sun, }}$ sunlight was allowed to fall over the fruit vegetables without any barrier which was considered as full sunlight level.

In treatment $\mathrm{T}_{\text {shade, }}$ plants were allowed to grow under Mahagony based agroforestry system which permitted reduced light intensitto reach to the vegetables. Three summer vegetables i.e $\mathrm{V}_{1}=$ chilli, $\mathrm{V}_{2}=$ Eggplant and $\mathrm{V}_{3}=$ Okra were sown under full sunlight $(100 \%$ PAR level) and partial shade following the Randomized Complete Block Design (RCBD) with single factor experiment. Three replications were used for each treatment for each crop. So, the total $6(3 \times 2)$ treatment combinations like $V_{1} T_{\text {shade, }}$ $\mathrm{V}_{2} \mathrm{~T}_{\text {shade, }} \mathrm{V}_{3} \mathrm{~T}_{\text {shade, }} \mathrm{V}_{1} \mathrm{~T}_{\text {sun }}, \mathrm{V}_{2} \mathrm{~T}_{\text {sun }}, \mathrm{V}_{3} \mathrm{~T}_{\text {sun, }}$ and total $18(6 \times 3)$ plots were set $\mathrm{up}$. Individual plot size for vegetables was $2.5 \mathrm{~m} \times 2 \mathrm{~m}$. Adjacent plots and neighboring blocks were separated by $0.5 \mathrm{~m}$ and $1 \mathrm{~m}$ respectively.

The seed of all vegetables were directly sown in the experimental plot in line sowing method maintaining $75 \mathrm{~cm}$ spacing on $7^{\text {th }}$ April, 2016. Recommended dose of well decomposed cowdung were applied for all the crop species. Chemical fertilizer was applied as per the BARI (Bangladesh Agricultural Research Institute) recommendation fertilizers of this crop. Full amount of $\mathrm{P}, \mathrm{K}$ and well decomposed cowdung was incorporated during the final land preparation. Nitrogen fertilizers were applied in three equal installments [14]. Thinning and gap filling was done 10 days after the emergence to maintain the uniform plant growth. Ripcord 10 EC was sprayed at the rate of $1 \mathrm{~mm}$ with 1 litre water for two times at 15 days interval after seedling germination to control the insects. To keep free from weeds, weeding was done five times of experimental plots and control plots. The plots were irrigated seven times by using hose pipe and water cane to supply sufficient soil moisture for the vegetables.

Vegetables were harvested for 3 times for a period of 15 days long at 5 days interval. Plant samples were collected randomly from all rows of the respective plots. Five representative sample plants were selected from each row per plot for data collection. Sample plants were collected based on suitable size for consumption.

Light was measured by Lux meter on each vegetable crop rows. It was done to determine the extent of shading by Mahagany Agroforestry system and expressed as lux. Light intensities were measured above the canopy of vegetable crops at $9.00 \mathrm{am}-10.00 \mathrm{am}, 1.00 \mathrm{am}-2.00 \mathrm{pm}$ and $4.00 \mathrm{am}-5.00$ pm using Lux meter at 10 days interval and collected data were averaged and expressed as lux. The data collected for different parameters were statistically analyzed to find out the significant difference of summer vegetables under reduced light conditions based agroforestry system. The mean values of all the characters were calculated and analysis of variance was calculated by the ' $F$ ' (variance ratio) test. The significance of the variation among the treatment means was estimated by the Least Significant Difference (LSD) at $1 \%$ and $5 \%$ level of probability [15].

\section{RESULTS AND DISCUSSION}

\subsection{Climate Parameters}

\subsubsection{PAR Availability on the Crop Rows}

Percent of Photosynthetically Active Radiation (PAR) refers to the fraction of quanta (radiation energy) which could be absorbed by the photo synthetically active pigment (Chlorophyll) of green leaves of plants. According to a study, incoming radiation in the open is combination of solar and atmospheric radiation [16]. Under the net there is also the net reflected and net radiated energy, less the amount of incident energy which is reflected and radiated by the top of the shade back into the atmosphere. Incoming radiation at the soil surface under the shade net is affected by the shade net. The net reflects a part of the total energy incident upon it and absorbs some of the energy which is then reradiated out as long wave energy.PAR availability was measured to determine the extent of limiting radiation by Mahagani Agroforestry system on the understory vegetable rows. PAR for different crops in sun and shade conditions which was measured as presented below.

Table 1: PAR availability in the different crop rows from March to June'16

\begin{tabular}{|llll|}
\hline $\begin{array}{l}\text { Light condition } \\
\text { (kilo lux) }\end{array}$ & Okra & Eggplant & Chilli \\
\hline Shade & 37.51 & 48.78 & 43.67 \\
Sun & 62.43 & 65.39 & 75.58 \\
$\begin{array}{l}\text { Reduction of } \\
\text { light }\end{array}$ & $39.9 \%$ & $25.42 \%$ & $42.23 \%$ \\
\hline
\end{tabular}

\subsubsection{Soil Temperature}

Mean monthly soil temperature for March was $32.3^{\circ} \mathrm{C}$ in the shade and $33.5^{\circ} \mathrm{C}$ in the open. The highest temperature was recorded in April- $35.7^{\circ} \mathrm{C}$ in sun and $34.2^{\circ} \mathrm{C}$ in shade. In the months of May and June temperature was reduced from $34.7^{\circ} \mathrm{C}$ to $33.7^{\circ} \mathrm{C}$ in open condition and from $33.5^{\circ} \mathrm{C}$ to $32.1^{\circ} \mathrm{C}$ in shaded condition. This is presented as the graphical presentation as below -

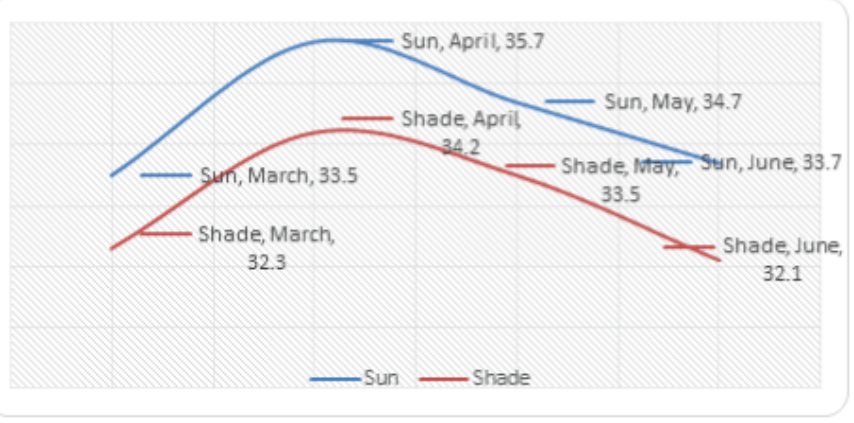

Figure 1: Sun and Shade effects on soil temperature from the months of March to June'16 


\subsubsection{Soil Moisture}

Mean monthly soil moisture for March was 15.3\% in the shade and 18.5\% in the open. The soil moisture was reduced in sun to $13.7 \%$ and increased to $16.8 \%$ in the shade. The highest soil moisture was recorded in June both in open and shade as $39.3 \%$ and $28.5 \%$ followed by May where soil moisture was $27.8 \%$ and $22.3 \%$ in sun and shade respectively. This is presented as the graphical presentation as below.

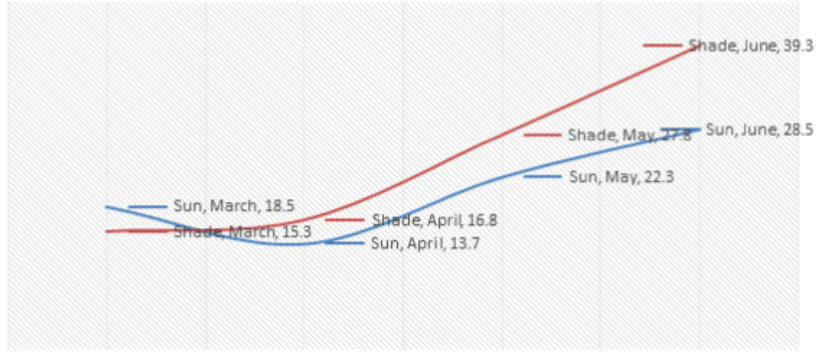

Figure 2: Sun and Shade effects on soil moisture from the months of March to June'16

\subsection{Morphological characteristics of fruit vegetables under reduced light condition}

\subsubsection{OKRA}

\subsubsection{Plant Height}

Plant height of Okra grown under different light levels was influenced significantly (Table 2). The plant height increased drastically with increased shaded condition level. In 100\% PAR or in sunlight plant height was $74.34 \mathrm{~cm}$ whereas in shade condition $\left(\mathrm{T}_{\text {shade }}=\right.$ Planting summer vegetables under reduced light) it was increased to $112.37 \mathrm{~cm}$. This was may be due to higher apical dominance under shade condition [12]. Similar to this crop higher plant height under reduced light levels was observed in mungbean and in chickpea [17-19]. This may be attributed due to the stimulation of cellular expansion and cell division under shaded condition [20]. The increase in plant height with corresponding increase of plant population was due to the less light penetration through the canopy which was also reported by Fawusi [21]. The crop in open field has received more light than the shade treatment and eventually the plant remained shorter than that of reduced light condition treatment. Increased plant height due to the effect of polythene shade was reported in maize by lzakobic and Duhr and Dubas [22, 23].

\subsubsection{Number of leaves per plant}

Total number of leaves per plant of Okra was significantly influenced by reduced light levels (Table 2). This parameter showed a similar trend to that of plant height as it increased with reduced PAR level (Photosynthetically Ative Radiation). The higher number of leaves per plant was seen in shade (28.12) compared to that of sunlight $\left(\mathrm{T}_{\text {sun }}=\right.$ Planting summer vegetables under full sunlight (100\% PAR level) (control)) condition (22.33). But more reduction of light e.g; 25\% PAR or less is very harmful for leaf production. Other researchers found mumber of leaves was greater in sole crops because of vigorous growth and plenty of food materials production \& uptake in their experiment [24]. They also stated that increased plant density (multistoried) was found to reduce leaf number \& thereby leaf area per plant similar result was also found by Wadud in case of okra $[25,26]$.

\subsubsection{Number of branch}

Different light levels had different effects on the number of branch per plant, where the higher number of branches was recorded under full sunlight level (10.00) compared to that of shaded condition (7.75). The lower number of branches under shaded condition might be due to higher Auxin production in plant which ultimately suppressed the growth of lateral branches.

\subsubsection{Plant Diameter}

Plant stem base diameter is the indicator of healthy plant on which yield is dependent. Plant base diameter of Okra was significantly influenced by different PAR levels (Table 2). Plant base diameter of Okra grown under full PAR under the treatment $T_{\text {sunwas recorded as }} 17.62 \mathrm{~mm}$ but increased remarkably when grown under reduced light or PAR level $(21.16 \mathrm{~mm})$.

\subsubsection{Leaf Chlorophyll Content}

Leaf chlorophyll content of Okra was drastically lower (52.37 SPAD unit) in reduced light level than that of sunlight condition (100\% PAR level) (58.33 SPAD unit).

\subsubsection{Height to base of crown (cm)}

Height to base of crown was significantly influenced in case of Okra by different PAR levels (Table 2). Highest height to base of crown $(52.03 \mathrm{~cm}$ ) was observed under shade condition under the treatment $\mathrm{T}_{\text {shade, }}$, while the lowest height to base of crown $(36.01 \mathrm{~cm})$ was seen in full sunlight condition under the treatment $\mathrm{T}_{\text {sun }}$

\subsubsection{Width of crown (cm)}

Reduced light level had highly significant influence on the width of crown of Okra. From the Table 2 it was found that the highest width of crown $(83.00 \mathrm{~cm})$ was found in reduced light or PAR level- shade condition under the treatment $\mathrm{T}_{\text {shade }}$ and lowest $(62.55 \mathrm{~cm})$ in open field $\left(\mathrm{T}_{\text {sun }}\right)$ condition .

\subsubsection{No of flower cluster/plant}

Number of Okra flower cluster per plant was recorded as significant in shade condition under the treatment $T_{\text {shade }}$ compared to full sunlight under the treatment $\mathrm{T}_{\text {sun. }}$. From the table it was noted that in treatment $\mathrm{T}_{\text {shade }}$ maximum number of flower clusters were recorded as 9.79 and in full sunlight or in treatment $\mathrm{T}_{\text {sun }}$ it was recorded as 7.49.

\subsubsection{No of fruits/plant}

The highest number of fruits (25.53) per plant was produced when okra grown in reduced light level under the treatment $\mathrm{T}_{\text {sun, }}$ which was significantly higher compared to the lowest number of fruits (20.81) per plant produced under treatment $\mathrm{T}_{\text {shade }}$ (Table2). Rahman conducted an experiment on okra under different colored polythene shades and found maximum number of fruits per plant under red colored polythene shade [17]. This present investigation was supported by Aldazabal and Zamora [14].

\subsubsection{Single fruit weight (g)}

Single fruit weight did not respond significantly with the reduced light level as it was recorded as $28.04 \mathrm{gm}$ and $26.87 \mathrm{gm}$ under treatment $\mathrm{T}_{\text {shade }}$ and treatment $\mathrm{T}_{\text {sun }}$ respectively.

\subsubsection{Single fruit length $(\mathrm{cm})$}

Reduced light level had significant influence on the single fruit length of Okra. In the Table it was found that the highest single fruit length $(18.72$ $\mathrm{cm}$ ) was found in reduced light level- shade condition under the treatment $\mathrm{T}_{\text {shade }}$ and lowest $(14.73 \mathrm{~cm})$ in open field $\left(\mathrm{T}_{\text {sun }}\right)$ condition.

\subsubsection{Single fruit girth $(\mathrm{cm})$}

Different light levels significantly influenced the single fruit girth. The highest girth of individual fruit $(4.61 \mathrm{~cm})$ was produced in full PAR condition under the treatment $\left(\mathrm{T}_{\text {sun }}\right)$ and the lowest single fruit girth (4.41) was recorded under the treatment $\mathrm{T}_{\text {shade }}$ in reduced light. Hanif (2010) stated that the lower fruit girth under heavy shade probably associated with the lower mobilization of reserve assimilation to reproductive organ. Incase of okra and eggplant similar finding was also reported by Wadud and Rahman respectively $[12,17]$.

\subsubsection{Yield per plot and per hectare}

It was observed that there was significant difference in respect of yields per plot and per hectare of Okra by the different PAR levels. The highest yield per plot $(11.25 \mathrm{~kg})$ was found when Okra grown under full PAR condition $\left(\mathrm{T}_{\mathrm{sun}}\right)$. On the other hand, the lowest yield per plot $(10.71 \mathrm{~kg})$ was recorded when Okra was cultivated under shade condition $\left(\mathrm{T}_{\text {shade }}\right.$ ). (Table 2). The lowest yield per hectare (21.44 ton)was found when Okra grown under full PAR condition ( $\mathrm{T}_{\text {sun }}$ ). On the other hand, the highest yield per plot (21.66 ton) was recorded when Okra was cultivated under shade condition ( $\mathrm{T}_{\text {shade }}$ ) (Table 2$)$. 


\subsubsection{EGGPLANT}

\subsubsection{Plant Height}

Plant height of Eggplant grown under different light levels was influenced significantly (Table 3). The plant height increased drastically with full sunlight level. In 100\% PAR or in sunlight plant height was $54.89 \mathrm{~cm}$ whereas in shade condition it was increased to $65.44 \mathrm{~cm}$. This was may be due to higher apical dominance under shade condition [9].

\subsubsection{Number of leaves/plant}

Total number of leaves per plant of eggplant was also significantly influenced by reduced light level (Table 3 ). This parameter showed a trend that plant height as it increased with increased percent of PAR level. The higher number of leaves per plant was seen in sunlight (105.63) compared to that of shade condition (71.89). This might be due to higher sunlight was absorbed in full PAR so higher number of leaves were produced.

\subsubsection{Number of branches/plant}

Different light levels had different effects on the number of branch per plant, where the higher number of branches (13.20) was recorded under $100 \%$ PAR level under treatment $\mathrm{T}_{\text {sun }}$ compared to that of shaded condition (10.03). The lower number of branches under shaded condition might be due to higher Auxin production in plant which ultimately suppressed the growth of lateral branches.

\subsubsection{Plant Diameter}

Plant base diameter of eggplant was significantly influenced by different PAR levels (Table 6). Plant base diameter of eggplant grown under full PAR was recorded as 14.30 but decreased when grown under 50 percent PAR level (13.21).

\subsubsection{Height to base of crown (cm)}

Crown height of eggplant was slightly influenced by different PAR level (Table 3). Under full PAR it was recorded as $32.10 \mathrm{~cm}$ and increased when grown under reduced light level $(34.08 \mathrm{~cm})$.

\subsubsection{Width of crown (cm)}

Varying crown width was resulted due to different level of light. In $100 \%$ PAR condition it was observed as $48.19 \mathrm{~cm}$ which was increased $(61.42$ $\mathrm{cm}$ ) at reduced light condition.

\subsubsection{No of flower cluster/plant}

Number of eggplant flower cluster was increased in full sunlight condition (12.73) compared to shade condition (6.52).

Table 2: Growth and yield contributing characters of Okra under control (full sunlight) and under under Mahogany based agroforestry system.

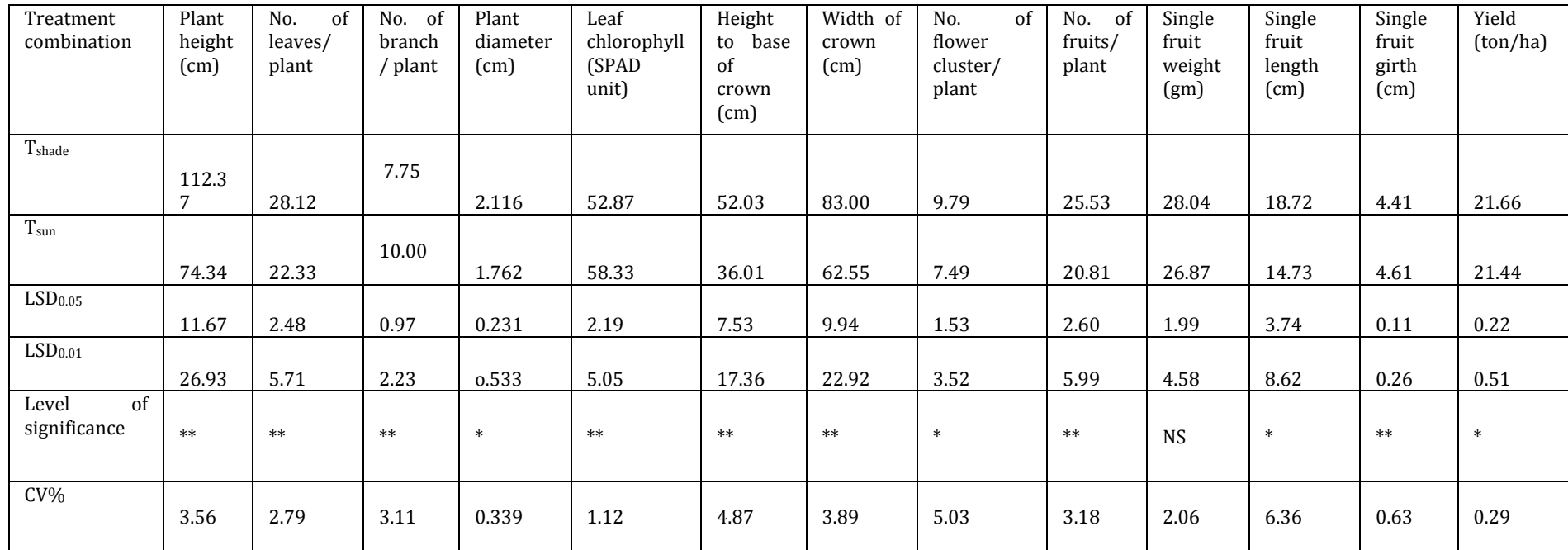

$\mathrm{T}_{\mathrm{sun}}=$ Planting summer vegetables under full sunlight (control)

$\mathrm{T}_{\text {shade }}=$ Planting summer vegetables under reduced light intensity

Table 3: Growth and yield contributing characters of Eggplant under control (full sunlight) and under Mahogany based agroforestry system

\begin{tabular}{|c|c|c|c|c|c|c|c|c|c|c|c|c|c|}
\hline $\begin{array}{l}\text { Treatment } \\
\text { combination }\end{array}$ & $\begin{array}{l}\text { Plant } \\
\text { height } \\
\text { (cm) }\end{array}$ & $\begin{array}{l}\text { No. of } \\
\text { leaves/ } \\
\text { plant }\end{array}$ & $\begin{array}{l}\text { No. of } \\
\text { branch } \\
\text { / plant }\end{array}$ & $\begin{array}{l}\text { Plant } \\
\text { diameter } \\
\text { (cm) }\end{array}$ & $\begin{array}{l}\text { Leaf } \\
\text { chlorophyll } \\
\text { (SPAD } \\
\text { unit) }\end{array}$ & $\begin{array}{l}\text { Height } \\
\text { to base } \\
\text { of } \\
\text { crown } \\
(\mathrm{cm})\end{array}$ & $\begin{array}{l}\text { Width of } \\
\text { crown } \\
(\mathrm{cm})\end{array}$ & $\begin{array}{l}\text { No. of } \\
\text { flower } \\
\text { cluster/ } \\
\text { plant }\end{array}$ & $\begin{array}{l}\text { No. of } \\
\text { fruits/ } \\
\text { plant }\end{array}$ & $\begin{array}{l}\text { Single } \\
\text { fruit } \\
\text { weight } \\
\text { (gm) }\end{array}$ & $\begin{array}{l}\text { Single } \\
\text { fruit } \\
\text { length } \\
\text { (cm) }\end{array}$ & $\begin{array}{l}\text { Single } \\
\text { fruit } \\
\text { girth } \\
(\mathrm{cm})\end{array}$ & $\begin{array}{l}\text { Yield } \\
\text { (ton/ha) }\end{array}$ \\
\hline $\mathrm{T}_{\text {sun }}$ & 54.89 & 105.63 & 13.20 & 1.430 & 47.53 & 32.10 & 48.19 & 12.73 & 9.52 & 78.87 & 21.14 & 3.17 & 22.63 \\
\hline $\begin{array}{l}\text { Level of } \\
\text { significance }\end{array}$ & 7.32 & 26.26 & 4.03 & 0.145 & 1.76 & 0.51 & 3.10 & 5.22 & 1.15 & 6.56 & 7.00 & 0.85 & 0.51 \\
\hline
\end{tabular}

$\mathrm{T}_{\mathrm{sun}}=$ Planting summer vegetables under full sunlight (control)

$\mathrm{T}_{\text {shade }}=$ Planting summer vegetables under reduced light intensit 


\subsubsection{No of fruits/plant}

The most impressive contribution to fruit yield of eggplant is the number of edible fruit per plant. Light levels had significant influence on the number of fruit per plant of eggplant (Table 3). Sunlight (100\% light) produced the higher number (9.52) of fruits per plant than shade (4.54). Lower number of fruits per plant under relatively more and prolong shaded condition was may be due to poor photosynthetic capacity of plants. The decrease in photosynthetic capacity of plant under shaded was attributed to both stomatal and mesophyll cell properties [24].

\subsubsection{Single fruit weight $(g)$}

Single fruit weight of eggplant varied significantly irrespective of light levels. Single fruit weight was increased at full level of PAR, where decreased (66.25g) in shaded condition.

\subsubsection{Single fruit length $(\mathrm{cm})$}

Under shade level length of single fruit was lower $(16.33 \mathrm{~cm})$ than full sunlight condition $(21.14 \mathrm{~cm})$. The present results are in support of Rahman who found the highest number of fruits per plant in the open field when eggplant grown as agroforestry system [14].

\subsubsection{Single fruit girth $(\mathrm{cm})$}

Fruit girth of eggplant varieties varied significantly irrespective light levels. The fruit girth decreased with the decrease of light level. In 100\% sunlight girth was $3.17 \mathrm{~cm}$ where $2.72 \mathrm{~cm}$ was found in shaded condition. The lower fruit girth under heavy shade probably associated with the lower mobilization of reserve assimilation to reproductive organ. Incase of eggplant similar finding was reported by Wadud and Rahman respectively $[12,17]$.

\subsubsection{Yield per plot and per hectare}

It was observed that there were significant variations in respect of yields per plot and per hectare of eggplant by the different PAR levels. The highest yield per plot (11.35 kg) and yield per hectare $(22.63 \mathrm{t})$ were found when in eggplant grown under full sunlight condition $\left(\mathrm{T}_{\text {sun }}\right)$. On the other hand, the lowest yield per plot $(8.20 \mathrm{~kg})$ and yield per hectare $(16.07 \mathrm{t})$ were recorded when Indian spinach was cultivated under shade condition ( $\mathrm{T}_{\text {shade }}$ ) (Table 3$)$.

\subsubsection{CHILLI}

\subsubsection{Plant height}

Plant height of Chilli grown under different light levels was influenced significantly (Table 4). The plant height increased drastically with full sunlight level. In $100 \%$ PAR or in sunlight plant height was $70.70 \mathrm{~cm}$ whereas in shade condition it was decreased to $64.65 \mathrm{~cm}$.

\subsubsection{Number of leaves/plant}

Total number of leaves per plant of Chilli was also significantly influenced by reduced light level (Table 4 ). This parameter showed a trend that plant leaves number as it increased with increased percent of PAR level. The higher number of leaves per plant was seen in sunlight (423.13) compared to that of shade condition (370.67). This might be due to higher sunlight was absorbed in full PAR so higher number of leaves were produced.

\subsubsection{Number of branches/plant}

Different light levels had different effects on the number of branch per plant, where the greater number of branches was recorded under $100 \%$ PAR level (12.05) compared to that of shaded condition (6.05). The lower number of branches under shaded condition might be due to higher Auxin production in plant which ultimately suppressed the growth of lateral branches.

\subsubsection{Plant Diameter}

Plant base diameter of Chilli was significantly influenced by different PAR levels (Table 4). Plant base diameter of Chilli grown under full PAR was recorded as $11.39 \mathrm{~mm}$ but decreased when grown under reduced PAR level $(9.94 \mathrm{~mm})$.

\subsubsection{Leaf Chlorophyll Content}

Leaf chlorophyll content of chilli was higher (76.23 SPAD unit) in full PAR $\left(\mathrm{T}_{\text {sun }}\right)$ level than that of shade condition ( $\left.\mathrm{T}_{\text {shade }}\right)$ 73.63 SPAD unit. This may be due to in shaded condition leaves were more green for a longer period of time than full sunlight condition. In full sunlight leaves were thrived in more light so they were yellowed.

\subsubsection{Height to base of crown (cm)}

Height to base of crown was significantly influenced in case of chilli by different PAR levels (Table 4). Highest height to base of crown $(36.37 \mathrm{~cm})$ was observed under shade condition under the treatment $\mathrm{T}_{\text {shade, }}$ while the lowest height to base of crown $(34.03 \mathrm{~cm})$ was seen in full sunlight condition under the treatment $\mathrm{T}_{\text {sun }}$

\subsubsection{Width of crown (cm)}

Reduced light level had significant influence on the width of crown of chilli. From the Table it was found that the lowest width of crown was found in $\mathrm{T}_{\text {shade }}$ condition $(42.34 \mathrm{~cm})$ and highest in open field condition $\left(\mathrm{T}_{\text {sun }}\right)(45.43$ $\mathrm{cm})$.

\subsubsection{No. of flower cluster/plant}

Height to base of crown was significantly influenced in case of chilli by different PAR levels (Table 4). Highest height to base of crown (32.88) was observed in full sunlight condition under the treatment $\mathrm{T}_{\text {sun }}$ while the lowest height to base of crown (17.5) was seen in shade condition under the treatment $\mathrm{T}_{\text {shade. }}$

\subsubsection{No of fruits/plant}

The most impressive contribution to fruit yield of chilli is the number of fruit per plant. Light levels had significant influence on the number of fruit per plant of eggplant (Table 4$)$. Sunlight (100\% light) produced the higher number (31.15) of fruits per plant than shade (16.04). Lower number of fruits per plant under relatively more and prolong shaded condition was probably due to poor photosynthetic capacity of plants. The decrease in photosynthetic capacity of shaded plant was attributed to both stomatal and mesophyll cell properties [26].

\subsubsection{Single fruit weight $(g)$}

Single fruit weight did not respond significantly as the highest weight (1.32 gm) of single fruit was reported in full sunlight, where in reduced light intensity, Single fruit weight was lowest.

\subsubsection{Single fruit length $(\mathrm{cm})$}

Under reduced light level, length of single fruit was lower $(4.73 \mathrm{~cm})$ than full sunlight condition $(6.0 \mathrm{~cm})$ and this was insignificant.

\subsubsection{Single fruit girth $(\mathrm{cm})$}

Girth of fruit of chilli varieties varied significantly irrespective light levels. The fruit girth decreased with the decrease of light level. In 100\% sunlight girth was $0.62 \mathrm{~cm}$ where $0.45 \mathrm{~cm}$ was found in shaded condition.

\subsubsection{Yield per plot and per hectare}

It was reported that there were significant variations in respect of yields per hectare of chilli by the different PAR levels. The highest yield per hectare $(8.06 \mathrm{t})$ were found when chilli plants grown under full sunlight condition $\left(\mathrm{T}_{\text {sun }}\right)$. On the other hand, the lowest yield per plot $(0.60 \mathrm{~kg})$ and yield per hectare $(5.41 \mathrm{t})$ were recorded when Indian chilli was cultivated under shade condition ( $\left.\mathrm{T}_{\text {shade }}\right)$ (Table 4$)$. 
Table 4: Growth and yield contributing characters of Chilli under control (full sunlight) and under Mahagony based agroforestry system

\begin{tabular}{|c|c|c|c|c|c|c|c|c|c|c|c|c|c|c|}
\hline $\begin{array}{l}\text { Treatment } \\
\text { combination }\end{array}$ & $\begin{array}{l}\text { Plant } \\
\text { heigh } \\
\mathrm{t}(\mathrm{cm})\end{array}$ & $\begin{array}{l}\text { No. of } \\
\text { leaves/ } \\
\text { plant }\end{array}$ & $\begin{array}{l}\text { No. of } \\
\text { branch } \\
\text { / plant }\end{array}$ & $\begin{array}{l}\text { Plant } \\
\text { diamete } \\
\mathrm{r}(\mathrm{mm})\end{array}$ & $\begin{array}{l}\text { Leaf } \\
\text { chlorophyll } \\
\text { (SPAD unit) }\end{array}$ & $\begin{array}{l}\text { Height } \\
\text { to base } \\
\text { of } \\
\text { crown } \\
\text { (cm) }\end{array}$ & $\begin{array}{l}\text { Width of } \\
\text { crown } \\
\text { (cm) }\end{array}$ & $\begin{array}{l}\text { No. of } \\
\text { flower } \\
\text { cluster/ } \\
\text { plant }\end{array}$ & $\begin{array}{l}\text { No. of } \\
\text { fruits/ } \\
\text { plant }\end{array}$ & $\begin{array}{l}\text { Single } \\
\text { fruit } \\
\text { weight } \\
\text { (gm) }\end{array}$ & $\begin{array}{l}\text { Single } \\
\text { fruit } \\
\text { length } \\
(\mathrm{cm})\end{array}$ & $\begin{array}{l}\text { Single fruit } \\
\text { girth }(\mathrm{cm})\end{array}$ & $\begin{array}{l}\text { Yield } \\
\text { (kg/plot) }\end{array}$ & $\begin{array}{l}\text { Yield } \\
\text { (ton/ha) }\end{array}$ \\
\hline $\mathrm{T}_{\text {shade }}$ & 64.65 & 370.67 & 6.05 & 9.94 & 73.63 & 36.37 & 42.34 & 17.50 & 16.04 & 0.96 & 4.73 & 0.45 & 0.60 & 5.41 \\
\hline $\mathrm{T}_{\text {sun }}$ & 70.70 & 423.13 & 12.05 & 11.39 & 76.23 & 34.03 & 45.43 & 32.88 & 31.15 & 1.32 & 6.03 & 0.62 & 0.87 & 8.06 \\
\hline LSD $_{0.05}$ & 2.21 & 3.03 & 0.57 & 0.87 & 1.29 & 0.29 & 0.58 & 1.14 & 0.11 & 0.42 & 1.34 & 0.16 & 0.11 & 0.35 \\
\hline LSD $_{0.01}$ & 5.09 & 6.98 & 1.31 & 2.02 & 2.97 & 0.68 & 1.33 & 2.63 & 0.26 & 0.96 & 3.09 & 0.36 & 0.26 & 0.81 \\
\hline $\begin{array}{l}\text { Level of } \\
\text { significance }\end{array}$ & ** & $* *$ & $* *$ & ** & ** & ** & ** & $* *$ & ** & NS & NS & * & ** & ** \\
\hline CV (\%) & 0.93 & 0.22 & 1.79 & 2.33 & 0.49 & 0.24 & 0.37 & 1.29 & 0.15 & 10.29 & 7.08 & 8.25 & 89.77 & 1.51 \\
\hline
\end{tabular}

$\mathrm{T}_{\text {sun }}=$ Planting summer vegetables under full sunlight (control)

$\mathrm{T}$ shade $=$ Planting summer vegetables under reduced light intensity

\section{CONCLUSION}

In the experiment it is clear that among fruit vegetables Okra gave the highest yield in shade treatment. So, Okra under agroforestry systems allowing reduced light intensity might be encouraged in rural Bangladesh. Further studies are suggested at different regions of Bangladesh to detect better vegetables under different light conditions for regional adaptability.

\section{REFERENCES}

[1] BBS. 2015. Statistical Year Book of Bangladesh. Bangladesh Bureau of Statistics. Ministry of Planning, Government of the people's Republic of Bangadesh,Dhaka, Bangladesh.

[2] Hossain, S.M.A., Bari, M.N. 1996. Agroforestry farming system. In: Hogue, M.A. (ed.), Agroforestry in Bangladesh, Village and Farm Forestry Project. SDC. Dhaka and Bangladesh Agrilcultural University, Mymensingh, 21-29.

[3] BFD. 2015. Homepage, Bangladesh Forest Department, www.bforest.gov.bd. Website accessed on 5 December.

[4] Akter, M.S., Abedin, M.Z., Quddus, M.A. 1989. Why farmers grow trees in agricultural fields: some thoughts, some results. Research Report, On Farm Research Division, Joydebpur,75-82.

[5] FAO. 2011. State of the world's forests, Food and Agriculture Organization of the United Nations, Rome.

[6] Hossain, M.K. 1999. Shade effect on the yield and quality of pineapple in a jackfruit-pineapple agroforestry system. M. S. Thesis, Department of agroforestry and Environment, Bangabondhu Sheik Mujibur Rahman Agricultural University, Gazipur, 57.

[7] Chowdhury, R.A., Hossain, M.Z. 1989. Forest management practices in Bangladesh. Traditional Practice and Alternative Approaches. Paper presented in a seminar in Forest Resource Management in Bangladesh, Chittagong.

[8] Nair, P.K.R. 1980. Effect of partial shading on the yield of rice. Indian Journal of Agricultural Science, 57, 193-205.

[9] Zenia, M., Halina, B. 2008. Content of micro elements in Eggplant fruits depending on Nitrogen fertilization and plant training method. Journal of Elementology, 13, 269-275.

[10] Rao, L.G., Mittra, B.N. 1988. Growth and yield of pea nut as influenced by degree and duration of shading. Journal of Agronomy and Crop Science, 160,
260-265.

[11] Schoch, P.G. 1972. Effects of shading on structural characteristics of the leaf and yield fruit in Capsicum annum L. Journal of American Society and Horticultural Science 97, 461-464.

[12] Rashid, M.A., Ahmad, M.S., Hussain, M.A., Hussain, A.M.M.A. 1985 Gimakalmi-a new leafy vegetable for rainy season of Bangladesh. Bangladesh Horticulture, 13, 79-81.

[13] Valli, V., Bryan, J.H.H., Young, H.W.1965. The effect of shade on the bioclimate and production of vegetable crops. Proceedings of the Florida State Horticultural Society, 78, 95-101.

[14] Akbar, G., Ahmad, M.R., Babar, K.N. 1990. Effect of trees on the yield of wheat crops. Agroforestry systems, 11, 1-10.

[15] Ali, M.A. 1999. Performance of Red amaranth and Ladys finger growth at different orientations and distances under Guava and Drumstick trees. MS. Thesis. BSMRAU, Gazipur, Bangladesh, 27-32.

[16] Islam, M.S., Wadud, M.A., Hasan, M.K., Rahman, M.M., and Rahman, G.M.M. 2009. Performance of three winter vegetables in association with Telsur (Hopeaodorata). Journal of Agroforestry and Environment, 3, 73-76.

[17] Murshed, A.N.M.M. 1996. Influence of management conditions on growth, flowering and pod set, seed development and yield of chickpea. MS Thesis, BSMRAU, Gazipur, Bangladesh, 27-32.

[18] Schoch, P.G. 1972. Effects of shading on structural characteristics of the leaf and yield fruit in Capsicum annum L. Journal of American Society and Horticultural Science, 9, 461-464.

[19] Fawusi, A.O.A. 1985. Influence of spatial arrangements on the growth, fruit and grain yields and yield components of intercropped maize and okra. Field crops Research, 11, 345-352.

[20] Jadhav, B.B. 1987. Effect of partial shading on the yield or rice. Indian Journal of Agricultural Science, 57, 193-205.

[21] Ding, S., Su, P. 2010. Effects of tree shading on maize crop within a Poplarmaize compound system in Hexi Corridor oasis. Agroforestry System, 80, 117-129.

[22] Muoneke, C.O., Udeogalanya, A.C.C. 1991. Response of okra to plant density and pattern of plant arrangement in Nigeria. Indian Journal of Agricultural Science, 61, 726-730. 
[23] Wadud, M.A. 1999. Performance of four summer vegetable under reduced light conditions for Agroforestry system. M.S. thesis, BSMRAU, Bangladesh.

[24] Rachie, K.O. 1983. Intercropping tree legume with annual crops. Plant Research and Agroforestry, 13, 120-128.
[25] Aldazabal, M., Zamora, R. 2000. Flowering and fruiting of tomatoes (Lycopersicum esculentum Willd.) under full sunlight or shading, grown in the summer. Alimentaria, 37, 121-124.

[26] Woledge, J. 1997. The effects of shading and cutting treatments on the photosynthetic rate of ryegrass leaves. Annual Botany, 41, 1279-1286. 